\title{
Exploring the Impact of Strategic Flexibility on Business Model Innovation under the Open Innovation Activity: The Moderating Roles of Multiple Factors with Competitive Ties and Cooperative Ties
}

\author{
Wang Xin ${ }^{1}$ \\ ${ }^{1}$ School of Economics and Management, Shanghai Polytechnic University, Shanghai, P. R. China \\ Correspondence: Wang Xin, School of Economics and Management, Shanghai Polytechnic University, Shanghai \\ 201209, P. R. China.
}

Received: May 11, 2020

Accepted: June 11, 2020

Online Published: June 22, 2020

doi:10.5539/ibr.v13n7p80

URL: https://doi.org/10.5539/ibr.v13n7p80

\begin{abstract}
This paper proposed a research model exploring the link among strategic flexibility, innovation openness, business model innovation, and introduced two moderating roles into this model. The result shows that innovation openness plays a partly mediating role between strategic flexibility and business model innovation. Collaborator ties negatively moderating the relationship between resource flexibility and innovation openness, positively moderating the relationship between coordination flexibility and innovation openness; The moderating effect of competitor ties is the same. In addition, the results of three interaction shows that the relationship between resource flexibility and innovation openness is negatively moderated by high collaborator ties and high competitor ties, while positively moderated by high collaborator ties and high competitor ties.

It's suggested that enterprises effectively integrate the relationship between internal resources with external competitors and cooperators according to their own strategic flexibility characteristics, embedded open innovation activities in business.
\end{abstract}

Keywords: strategic flexibility, business model innovation, innovation openness, collaborator ties, competitor ties

Paper type: Research paper

\section{Introduction}

Open innovation, as an originality innovation mode, has been attracted wide attention from academia in recent years. Compared with the closed innovation, companies can conduct collaborative innovation through open innovation activities and coordination the internal /external resources to improve their competitive advantage. At the same time, in the field of competitive advantage management, especially in the field of strategic management and operational management, the relationship between flexibility and efficiency is regarded as a kind of enterprise flexibility. As a dynamic capability of enterprises, strategic flexibility is needed to adapt to unexpected situations and rapidly changing environments. This is because strategic flexibility supports resource utilization, process reengineering, and the ability to respond quickly to changing environments.

Business model innovation can provide opportunities for enterprises to benefit from the development of new technologies, and even reshape their business activities. In recent years, business model innovation has increasingly become an important topic of business management. In some mature industries, new products and process reengineering are already limited. At this time, business model innovation has advantages in cost and time over new product development and process reengineering, which can improve the company's competitive position. DELL, Southwest Airlines and IBM are relatively successful cases. However, business model innovation is a complex process, so Demil (2015) and other scholars suggest exploring the "black box" of business model innovation. Lee, Park, Yoon \& Park (2010) emphasized that the impact of market participants on business model innovation should be taken into account when studying the content of business model innovation.

Based on the above background, this paper will explore the impact of strategic flexibility on business model 
innovation based on the open innovation model of enterprises. The impact will be further analyzed from the perspective of market participants. This paper explores how to change the organizational environment to promote business model innovation by using the flexibility of enterprises when facing increasingly difficult to define the competitive and cooperative relationship.

\section{Literature Review}

Amit \& Zott (2010) points out that business model innovation is a process in which enterprises seek new logic in business, create and capture value. Therefore, business model innovation can be a new way to commercialize the existing assets of enterprises, or it can be a business model that is completely different from the existing business. Although there is no definite conclusion on the extent to which the change of the existing business model can be called business model innovation, it is worth mentioning that business model innovation is beyond pure product innovation or service innovation. scholars point out that business model innovation emphasizes creating new sources of value, developing new markets and requiring revision of existing systems. Therefore, business model innovation has great challenges for enterprises (Amit \& Zott(2010); Markides(2006)). Scholars such as Chesbrough $(2002,2010)$ have proposed that enterprises need to overcome some obstacles if they want to achieve successful business model innovation, such as resistance to change within enterprises, and even confusion about the need for change.

In this case, strategic flexibility has become an important ability for enterprises to overcome obstacles to business model innovation. Because strategic flexibility allows companies to flexibly redistribute resources, change or partially adjust their plans or strategies.

Hitt (1998), Zahra (2008) and other scholars believe that strategic flexibility is the source of competitive advantage for enterprises in complex environment. Eisenhardt, Furr and Bingham (2010) regard strategic flexibility as an important dynamic capability of an enterprise, which can become an effective new way for an organization to continuously create and reorganize resources. However, there haven't reach a consensus on the relationship between strategic flexibility and corporate performance. Some scholars believe that strategic flexibility has the characteristics of high investment cost and opportunity cost, so organizations that overemphasize strategic flexibility may lose other opportunities, such as some businesses that can benefit from scale economy. Existing literature shows that strategic flexibility can also reduce corporate performance, short-term profitability and operational efficiency. Zahra (2008) and others believe that strategic flexibility represents the company's willingness to change its original strategy in the face of changes in the external environment and market opportunities or threats. Scholars such as Hitt (1998) and Johnson (2003) point out that the ability of a company to change its strategy in time in a dynamic environment is extremely important to its competitive advantage. Existing literature shows that strategic flexibility is beneficial for companies to perceive changes in the external environment, overcome organizational inertia, redistribute resources, stimulate enterprise creativity and innovation, and develop new business opportunities. From these perspectives, strategic flexibility is conducive to promoting enterprise performance. However, in the literature review, it is also found that many scholars have different views on the role of strategic flexibility to corporate performance promotion, because strategic flexibility will bring high costs, increase business pressure and no corporate strategic focus. In the research of Nadkarni \& Narayanan (2007), 225 enterprises distributed in 14 industries were investigated, and it was pointed out that the impact of strategic flexibility on their performance is different in different industries. Other studies show that strategic flexibility promotes firm performance in a high-intensity market environment with uncertain demand and technology.

In the classification research of strategic flexibility, scholars have defined two categories: resource flexibility and coordination flexibility. Resource flexibility refers to the ability of enterprises to identify, acquire and use resources flexibly. This ability can provide other strategic choices for enterprises when they face changes in the competitive environment. Coordination flexibility is defined as maximizing the ability to make use of inherent resources. Scholars believe that resource flexibility is related to the technological level of the company, while coordination flexibility is related to the organizational characteristics of the enterprise. Then, how to realize the synergistic ability of these two strategic flexibility becomes a new research content within the enterprise.

In this context, this paper chooses the open innovation model as the breakthrough point to explore the black box mechanism between strategic flexibility to business model innovation. Existing literature shows that the turbulent market environment promotes enterprises to change from traditional business model to open innovation model (Laursen, K., Salter, A.J., 2014; Sabrina Schneider, Patrick Spieth., 2013). On the one hand, open innovation can promote the interaction of innovation participants and bring many benefits to enterprises, such as accelerating innovation, technology acquisition and resource development. On the other hand, because open 
innovation needs to establish cooperative relations with different partners, how to obtain useful external resources has become a realistic problem in the management research of open innovation.

Through literature review, we also find that both strategic flexibility and open innovation research need to consider resource allocation and resource flow, which are closely related to market participants. Therefore, in this study, we intend to introduce the concept of "managerial ties" to measure the environmental dynamics faced by enterprises from two aspects: competitor ties and collaborator ties. Guillen (2000) pointed out that manager ties facilitated the acquisition of external knowledge, technology and resources, which in turn facilitated the improvement of existing systems and procedures. Hoffmann \& Schlosser (2001); Van de Vrande (2009) further points out that good managerial ties can reduce the time and cost of R\&D knowledge within the company, minimize risks and meet the company's need to acquire the knowledge it lacks.

However, it has to be said that in the turbulent market environment, the role of competition and cooperation faced to the enterprises is increasingly difficult to clearly define in reality. Therefore, in this study, we try to explore the impact mechanism of strategic flexibility on business model innovation from the perspective of open innovation model, and explore the multiple impacts of collaborator ties and competitor ties on business model innovation from the perspective of market participants.

\section{Research Hypothesis}

\subsection{Strategic Flexibility and Business Model Innovation}

D'Aveni (2010) and Teece (1998) pointed out that the changing external environment has brought continuous innovation demand to enterprises, so enterprises need to establish higher flexibility to meet this innovation demand. Business model innovation is an enterprise's response to changes in its environment on the basis of expectations. This point can be seen in Teece's view of dynamic capabilities: capabilities enable enterprises to capture opportunities and threats related to the environment in time, then enterprises can gain competitive advantage by expanding, changing, redistributing or modifying existing resources.

In the past, many researches on business models were discussed from the perspective of enterprise strategy. Strategic flexibility is the ability of enterprises to identify changes in the external environment, to quickly invest resources in response to changes in behavior and actions, and to use resources freely. It includes not only the passive adaptation of enterprises to external environment, but also the ability of enterprises to change organizational environment by actions. Therefore, in this study, we will study business model innovation from the perspective of strategic flexibility. Sanchez $(1995,1996)$ divides strategic flexibility into resource flexibility and coordination flexibility. Resource flexibility focuses on the technological characteristics of enterprise resources, which is mainly manifested in the flexibility of the switching of specific resources in different departments and uses. Sanchez's research also summarizes several characteristics of resource flexibility, such as time cost of resource conversion and scope of resource transformation. Coordination flexibility is related to the organizational characteristics of enterprises, which is reflected in the process of resource coordination and excavation between enterprises or between internal and external enterprises. It can be seen that the difference between resource flexibility and coordination flexibility is that resource flexibility focuses on the scope of use of a specific technical attribute resources, while coordination flexibility focuses on the organization's ability to explore, integrate and utilize resources. Due to the different emphasis of resource flexibility and coordination flexibility, their impact on business model innovation may also be different.

Whether resource flexibility pays attention to resource flexibility in use or coordination flexibility pays attention to resource coordination among organizations, these are conducive to overthrowing the past business thinking, creating and capturing new value.

Based on this, this study proposes hypotheses:

H1: Strategic flexibility (resource flexibility, coordination flexibility) has a direct impact on business model innovation.

H1a: Resource flexibility has a direct impact on business model innovation.

H1b: Coordination flexibility has a direct impact on business model innovation.

\subsection{The Mediating Role of Innovation Openness}

In the study of the relationship between openness and performance, the conclusions are not consistent. Some conclusions show that openness has a positive impact on corporate performance. Some conclusions show that openness may increase the risk of imitation, so the impact on performance is negatively correlated (Laursen., Salte, 2006). Other scholars have found that this is related to the degree of open innovation, and different types 
of participation have different effects on enterprise performance. Katila \& Shane (2005) found that when an enterprise needs to seek external knowledge, the organization makes strategic choices on the type of its partners, so as to acquire the knowledge and technology needed, promote the performance. Most of these studies focus on manufacturing industry.

Research shows that companies can stride across the boundaries of space (geography), organization and technology when engaging in external search and collaboration. However, it is unclear how effective across a variety of boundary search and company search results in the creation of value, such as how to use different types of innovation partners provide support for the innovation of enterprises. On the other hand, there is a need for appropriate knowledge exchange between organizations. Excessive or insufficient knowledge exchange will make organizations lose their ideal partners. This is because in the process of innovation, openness is to facilitate the search of external knowledge or resources, but at the same time, internal knowledge needs to be protected from being duplicated by other enterprises. Therefore, appropriate openness can play a beneficial role in enterprise innovation.

Strategic flexibility emphasizes the allocation and coordination of resources, and openness is conducive to the acquisition of resources and technology needed by enterprises, then impact on innovation.

Based on this, this study proposes hypotheses.

H2: Strategic flexibility (resource flexibility, coordination flexibility) can influence business model innovation through innovation openness.

H2a: Resource flexibility can influence business model innovation through innovation openness.

$\mathrm{H} 2 \mathrm{~b}$ : Coordination flexibility can influence business model innovation through innovation openness.

\subsection{The Moderating Effect of Collaborator Ties and Competitor Ties}

Competitor ties and collaborator ties are two parts of managerial ties. Manager ties refers to the activities of executives with the outside world and the effects of such cross-border activities on enterprises. Some scholars believe that managerial ties are part of social capital and social exchange. Research shows that companies with strong management ties will have more opportunities to reach their ideal business partners and more access to external information and resources. Based on the research background, this study focuses on how the manager ties moderating the process from strategic flexibility to the business model innovation in the context of open innovation.

Collaborator ties mainly refers to the enterprise management with suppliers and customers. Takeishi (2001) points out that the relationship management between suppliers and customers is very important for knowledge development, transfer and resource scheduling. Suppliers can provide the necessary information and related technologies for enterprises, and enterprises can access more suppliers through some suppliers. Similarly, through customer relationship management, suppliers can also bring their own innovations to the market directly. Since the management relationship between suppliers and customers is mainly based on personal trust, so Shanxing Gao \& Kai Xu \& Jianjun Yang (2008) pointed this cooperation will promote innovation in a long-term and stable way.

The purpose of establishing links between companies and competitors is to reduce some uncertainties in competitive activities. Knowledge exchange with competitors provides an effective way to rapidly improve production efficiency, quality control and product innovation. This kind of communication can be said to be a convenient channel for knowledge exchange between enterprises, which can shorten the development cycle of new products (Peng \& Luo, 2000).

Ebersberger (2012) points out that companies search among customers, customers and competitors to improve their understanding of the market direction changes, and to find possible solutions or new directions of development among universities, research institutions, suppliers and competitors. Lazzarotti (2011) points out that the company's openness varies with the innovation process, the degree of innovation ideas and the progress of commercial development. Faems (2005) points out that vertical partners in the value chain, such as suppliers and customers, cooperate with them to help enterprises develop applied projects. Cooperating with suppliers can reduce the cost of product development. Some studies also show that firms look for suppliers outside their own industries to seek innovation opportunities. Grimpe \& Sofka (2009) studied non-high-tech industries and found that cooperation between enterprises and customers can also bring benefits to enterprises. Foss, Laursen \& Pedersen (2011) assumes that there is a positive correlation between customer collaboration and innovation performance, but regretfully there is not enough evidence to support this hypothesis in the article. Schamberger, Cleven \& Brette (2013) also assumes that the cooperation between companies and customers and suppliers can 
actively promote the enterprises' research capabilitie, but this research hypothesis has not been supported by empirical evidence. Veugelers \& Cassiman (1999) found that competitors can also bring new external knowledge to enterprises, such as shared patents as innovative products. Further, Schamberger, Cleven \& Brette (2013) studies also attempt to show that cooperation with competitors is negatively related to the enterprise's exploratory research projects, but positively related to the enterprise's exploitative research projects.

Based on the above research review, considering the factor of innovation openness, we find that in the current business situation, the evolution of cooperative-competition relationship is becoming more and more complex. From the perspective of resource view, we assume that resource flexibility and coordination flexibility within an enterprise can have different impacts on business model innovation through enterprise's open innovation activities, but in this process, the competitive relationship between the enterprise and its competitors and the cooperative relationship with upstream and downstream enterprises and even customers have a certain depth or breadth degree to the enterprise's innovation openness. In the modern business environment, sometimes competition and cooperation are also transforming each other. As mentioned above, there is not only cooperation but also competition between enterprises and suppliers or customers. Even sometimes competition is more than cooperation between them. At the same time, enterprises can also cooperate extensively with competing enterprises in the same industry. In many cases, cooperation is more than competition. Therefore, this study attempts to explore how the competitive-cooperative relationship of enterprises in the modern business environment essentially adjusts the impact of strategic flexibility on business model innovation. Based on this, the following research hypotheses are proposed.

H3: Strategic flexibility (resource flexibility, coordination flexibility) is moderated by collaborator ties, which influences business model innovation through innovation openness in the first half process.

H3a: Resource flexibility is moderated by collaborator ties, which influences business model innovation through innovation openness in the first half process.

H3b: Coordination flexibility is moderated by collaborator ties, which influences business model innovation through innovation openness in the first half process.

H4: Strategic flexibility (resource flexibility, coordination flexibility) is moderated by competitor ties, which influences business model innovation through innovation openness in the first half process.

H4a: Resource flexibility is moderated by competitor ties, which influences business model innovation through innovation openness in the first half process.

H4b: Coordination flexibility is moderated by competitor ties, which influences business model innovation through innovation openness in the first half process.

H5: Strategic flexibility (resource flexibility, coordination flexibility) is moderated by (collaborator ties *competitor ties), which influences business model innovation through innovation openness in the first half process.

H5a: Resource flexibility is moderated by (collaborator ties *competitor ties), which influences business model innovation through innovation openness in the first half process.

H5b: Coordination flexibility is moderated by (collaborator ties *competitor ties), which influences business model innovation through innovation openness in the first half process.

\subsection{Research Model}

Based on the theory of dynamic capability, resource endowment and open innovation, this study draws the research model of Figure 1 as below. According to the model, it is assumed that strategic flexibility can directly influence business model innovation, and can also influence business model innovation through related open innovation activities. Therefore, it is considered that innovation openness is a part of mediating role in this model. Secondly, it is assumed that not only the relationship between competitors and partners will have a moderating effect on the model, but also the cross-influence of competition and cooperation will have a moderating effect on the model in the first half of the process. 


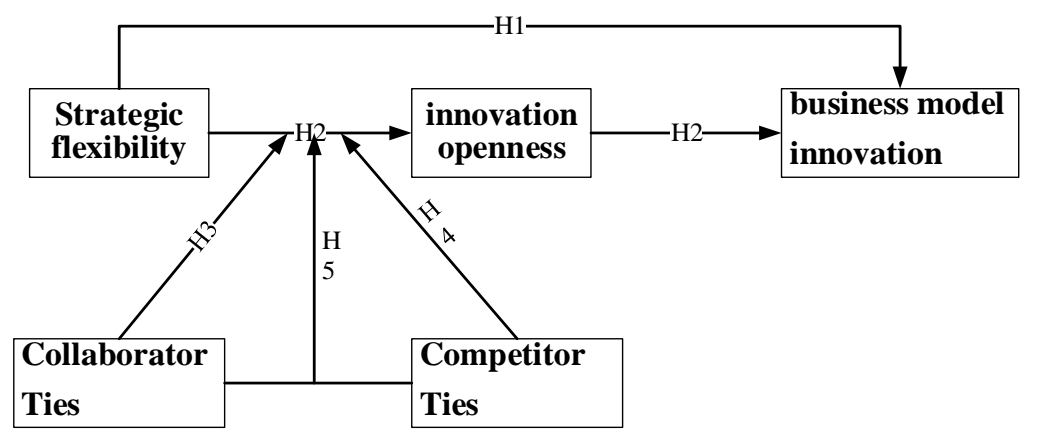

Figure 1. Research Model

\section{Research Methods}

\subsection{Sample Selection}

In order to verify the theoretical hypothesis put forward in this study, an initial questionnaire was designed by referring to the relevant literature. All the concepts in the questionnaire were selected from the mature scale provided in the literature. Based on this, a preliminary survey was conducted. According to the results of the preliminary survey and considering the real situation, some sentences of the items were adjusted. The final research data are selected from the questionnaire survey results of modern service-oriented enterprises in the Yangtze River Delta region from September 2017 to May 2018. Among them, 300 questionnaires were distributed, 258 questionnaires were retrieved and 236 valid questionnaires were valid.

Because the research subject of this study includes knowledge management, we choose modern service-oriented enterprises as the research object, and select knowledge-intensive services enterprises, online tourism platform enterprises and internet financial enterprises as the research object. Sample basic information as shown in Table 1 , in the enterprise age, the establishment of 2-5 years is most, in the company size, the majority is 100-500 staff, and enterprises in the industry are mostly in the growth stage.

Table 1. Sample Basic Information

\begin{tabular}{ccc}
\hline Features & classification & Proportion \% \\
\hline & $\leqq 2$ & 8.593 \\
Enterprise Age & $2-5$ & 34.218 \\
(year) & $5-10$ & 24.343 \\
& $10-15$ & 22.762 \\
& $\geqq 15$ & 10.084 \\
Enterprise Size & $\leqq 100$ & 12.205 \\
(staff) & $100-500$ & 33.825 \\
& $501-1000$ & 17.532 \\
& $1001-1500$ & 22.351 \\
The Industry Stage of Main & $1501-2000$ & 7.593 \\
Business & $\geqslant 2000$ & 6.494 \\
& Starting stage & 25.647 \\
& Growth stage & 45.775 \\
& Maturity stage & 24.232 \\
& Recession stage & 4.328 \\
\hline
\end{tabular}

\subsection{Variable Measurement}

All items were answered on a five-point Likert scale.

Independent variables: The scale of resource flexibility and coordination flexibility was taken from the study of Sanchez $(1995,1996)$.

Moderating variables: The scale of collaborator and competitor linkages was taken from Peng \& Luo (2000).

Mediating variables: The scale of innovation openness is based on Laursen \& Salter's research (2006, 2014), which is measured in both breadth and depth. 
Dependent variables: Business model innovation is measured from the perspectives of value, profit model and business model, according to Sabrina Schneider (2013).

Control variables: Enterprise age is calculated by calculating the survival time of the enterprise when the survey is carried out, and its natural logarithm is taken to ensure the normal distribution. Enterprise size is the natural logarithm of the total number of employees. The type of enterprise ownership is a fictitious variable (state-owned enterprises are marked 1, non-state-owned enterprises are marked 0).

\section{Date Analysis}

\subsection{Reliability and Validity Analysis}

We use SPSS software to test the latent variables' reliability and do validity analysis, found that all of the measurement in the structure factor load read was greater than 0.5 , the variance of all factor corresponding explanations are higher than 50 per cent, so it can be identified, the test dimension has good convergent validity.

As shown in Table 2, the factor loads of each measurement index ranged from 0.599 to 0.851 , all of which were greater than 0.5, and the Cronbach's alpha values of all variables were greater than 0.8 , which indicated that the reliability was good; the percentage of explanatory variance (AVE) was greater than 0.5 , indicating that the aggregation validity of the scale was good. In addition, the confirmatory factor analysis using AMOS shows that the measurement model fits well with the data. $\left(x^{2}=559.814, \mathrm{df}=335, \chi^{2} / \mathrm{df}=1.671, \mathrm{IFI}=0.903, \mathrm{CFI}=0.901\right.$, RMSEA=0.077)

Table 2. Reliability and validity of the scale

\begin{tabular}{|c|c|c|c|c|}
\hline Variable & Dimension & Measurement Item & $\begin{array}{l}\text { Factor } \\
\text { Loading }\end{array}$ & AVE \\
\hline \multirow{9}{*}{$\begin{array}{l}\begin{array}{l}\text { Strategic } \\
\text { flexibility }\end{array} \\
\text { Sanchez, } \\
(1995,1997) ; \\
\text { Zhou \& Wu, } \\
(2010)\end{array}$} & \multirow{5}{*}{$\begin{array}{l}\text { Resource } \\
\text { Flexibility } \\
\text { (Cronbach's } \alpha= \\
0.914)\end{array}$} & $\begin{array}{l}\text { The company's main resources have a wide } \\
\text { range of alternative uses; }\end{array}$ & 0.816 & \multirow{5}{*}{0.6103} \\
\hline & & $\begin{array}{l}\text { The company's main resources are less difficult } \\
\text { to change use; }\end{array}$ & 0.758 & \\
\hline & & $\begin{array}{l}\text { The company's main resources can be allocated } \\
\text { to the development, manufacturing and } \\
\text { diversification of product lines; }\end{array}$ & 0.804 & \\
\hline & & $\begin{array}{l}\text { The time required to switch the primary } \\
\text { resource used to the alternative resource is } \\
\text { short; }\end{array}$ & 0.665 & \\
\hline & & $\begin{array}{l}\text { The cost of switching the main resources used } \\
\text { to alternative resources is inexpensive; }\end{array}$ & 0.849 & \\
\hline & \multirow{4}{*}{$\begin{array}{l}\text { Coordination } \\
\text { Flexibility } \\
\text { (Cronbach's } \alpha= \\
0.877)\end{array}$} & $\begin{array}{l}\text { Internal units often collaborate to find new uses } \\
\text { for internal resources; }\end{array}$ & 0.743 & \multirow{4}{*}{0.576} \\
\hline & & $\begin{array}{l}\text { Companies often find new resources or new } \\
\text { combinations of existing resources; }\end{array}$ & 0.599 & \\
\hline & & $\begin{array}{l}\text { Companies often seek new resources through } \\
\text { communication between departments; }\end{array}$ & 0.817 & \\
\hline & & $\begin{array}{l}\text { Companies often find new resources or new } \\
\text { combinations of external resources; }\end{array}$ & 0.851 & \\
\hline \multirow{7}{*}{\multicolumn{2}{|c|}{$\begin{array}{l}\text { Innovation Openness } \\
\text { Laursen \& Salter } \\
(2006,2014) \\
(\text { Cronbach's } \alpha=0.935)\end{array}$}} & $\begin{array}{l}\text { The company has established cooperative } \\
\text { relations with many enterprises in the core } \\
\text { business circle; }\end{array}$ & 0.752 & \multirow{7}{*}{0.548} \\
\hline & & $\begin{array}{l}\text { The company has established cooperative } \\
\text { relations with many enterprises outside the core } \\
\text { business circle; }\end{array}$ & 0.803 & \\
\hline & & $\begin{array}{l}\text { The company has established cooperative } \\
\text { relations with many scientific research } \\
\text { organizations; }\end{array}$ & 0.648 & \\
\hline & & $\begin{array}{l}\text { The company has established partnerships with } \\
\text { more government agencies or non-profit } \\
\text { organizations; }\end{array}$ & 0.737 & \\
\hline & & $\begin{array}{l}\text { Companies often work with multiple external } \\
\text { organizations at the same time; }\end{array}$ & 0.731 & \\
\hline & & $\begin{array}{l}\text { Companies can quickly analyze and understand } \\
\text { market changes; }\end{array}$ & 0.656 & \\
\hline & & Companies can seek new market opportunities. & 0.837 & \\
\hline \multicolumn{2}{|c|}{ Business Model Innovation } & The company's business model is novel in the & 0.725 & 0.553 \\
\hline
\end{tabular}




\begin{tabular}{|c|c|c|c|}
\hline \multirow{5}{*}{$\begin{array}{l}\text { Sabrina Schneider } \\
(2013) \\
(\text { Cronbach's } \alpha=0.896)\end{array}$} & \multicolumn{2}{|l|}{ market; } & \\
\hline & $\begin{array}{l}\text { The company's business model contains new } \\
\text { ideas and values; }\end{array}$ & 0.662 & \\
\hline & $\begin{array}{l}\text { The company's business model introduces new } \\
\text { management processes and service modes; }\end{array}$ & 0.776 & \\
\hline & $\begin{array}{l}\text { The company's business model introduces new } \\
\text { management processes and service modes; }\end{array}$ & 0.776 & \\
\hline & $\begin{array}{l}\text { The company's business model provides } \\
\text { value-added products or services; }\end{array}$ & 0.773 & \\
\hline \multirow{4}{*}{$\begin{array}{l}\text { Collaborator Ties } \\
\text { Peng \& Luo,(2000); } \\
\text { Li et al., }(2011) \\
(\text { Cronbach's } \alpha=0.891)\end{array}$} & $\begin{array}{l}\text { The company has invested heavily in } \\
\text { establishing relationships with suppliers; }\end{array}$ & 0.771 & \multirow{4}{*}{0.596} \\
\hline & $\begin{array}{l}\text { The company believes it important to cultivate } \\
\text { and maintain a good relationship with suppliers; }\end{array}$ & 0.842 & \\
\hline & $\begin{array}{l}\text { The company has invested heavily in building } \\
\text { relationships with customers; }\end{array}$ & 0.665 & \\
\hline & $\begin{array}{l}\text { The company believes it important to cultivate } \\
\text { and maintain good relations with customers. }\end{array}$ & 0.800 & \\
\hline \multirow{3}{*}{$\begin{array}{l}\text { Competitor Ties } \\
\text { Peng \& Luo, }(2000) \text {; } \\
\text { Li et al., }(2011) \\
(\text { Cronbach's } \alpha=0.823)\end{array}$} & $\begin{array}{l}\text { The company has invested heavily in } \\
\text { establishing relationships with its competitors; }\end{array}$ & 0.844 & \multirow{3}{*}{0.598} \\
\hline & $\begin{array}{l}\text { The company ensures that it has a close } \\
\text { relationship with its competitors; }\end{array}$ & 0.635 & \\
\hline & $\begin{array}{l}\text { The company believes that it is important to } \\
\text { cultivate and maintain a good relationship with } \\
\text { its competitors. }\end{array}$ & 0.824 & \\
\hline
\end{tabular}

Then, the main variables were tested by descriptive statistics, as shown in Table 3. Table 3 is about the mean, standard deviation and correlation coefficient matrix of each variable. As can be seen from Table 3, the correlation coefficient between the independent variables is less than 0.7 , so there is no multicollinearity. The square root of the variance on the diagonal is larger than the correlation coefficient of the same column, which satisfies the requirement of the discriminant validity. We further calculated the variance expansion factor (VIF). The results show that the VIF of each variable is less than 10, excluding the influence of multiple collinearity.

Table 3. Summary statistics of the main variables

\begin{tabular}{|c|c|c|c|c|c|c|c|c|c|c|c|}
\hline & $\mathrm{M}$ & SD & 1 & 2 & 3 & 4 & 5 & 6 & 7 & 8 & 9 \\
\hline 1. Resource Flexibility & 3.556 & 1.099 & $(0.781)$ & & & & & & & & \\
\hline 2. Coordination Flexibility & 3.450 & 1.092 & $0.411 * *$ & $(0.759)$ & & & & & & & \\
\hline 3. Collaborator Ties & 3.798 & 1.025 & $0.275 * *$ & $0.253 * *$ & $(0.772)$ & & & & & & \\
\hline 4. Competitor Ties & 3.731 & 1.060 & $0.209 * *$ & $0.244 * *$ & $0.297 * *$ & $(0.774)$ & & & & & \\
\hline 5. Innovation Openness & 3.492 & 1.088 & 0.089 & 0.075 & $0.244 * *$ & $0.204 * *$ & $(0.740)$ & & & & \\
\hline 6. Business Model Innovation & 3.551 & 1.064 & $0.297 * *$ & $0.296 * *$ & $0.282 * *$ & $0.212 * *$ & $0.346 * *$ & $(0.744)$ & & & \\
\hline 7. Enterprise Age & 1.766 & 0.888 & 0.02 & 0.091 & 0.132 & 0.097 & -0.078 & -0.018 & 1 & & \\
\hline 8. Enterprise Size & 5.310 & 1.178 & 0.103 & 0.134 & 0.139 & 0.148 & -0.003 & 0.054 & $0.537 * *$ & 1 & \\
\hline 9. Types of Enterprise Ownership & 0.202 & 0.403 & 0.1 & 0.064 & 0.158 & 0.094 & 0.031 & -0.067 & $0.427 * *$ & $0.673 * *$ & 1 \\
\hline
\end{tabular}

Notes: Diagonal is the square root of the variance. $* * \mathrm{p}<0.01$

\subsection{Testing the Mediating Effect with Moderating Effect}

SPSS22.0 software was used to test hypothesis by multiple linear regression. In order to avoid multiple collinearity problems, independent variables and moderate variables are centralized before the product term is tested, the test results are shown in Table 4.

\section{Testing the Mediating Effect}

In this part, SPSS software was used to divide the analysis into eight models to test the mediating effect with moderating effect. The hypothesis testing models are listed in Table 4, in which Model 1 and Model 6 are the basic models with only control variables.

According to Baron's and Kenny's test steps, we first examine the mediating role of innovation openness.

(1) To test the direct effect of resource flexibility and coordination flexibility on business model innovation, independent variable (resource flexibility and coordination flexibility) is added to the basic model 6 to get model 7, which is used to test hypothesis H1. 
As shown in model 7, $\mathrm{R}^{2}=0.699$, adjusting $\mathrm{R}^{2}=0.683, \mathrm{~F}=43.581(\mathrm{P}<0.001)$; The test results prove that the research hypothesis H1, H1a and H1b: strategic flexibility (resource flexibility, coordination flexibility) has a direct positive impact on business model innovation $\left(\beta_{\text {resource flexibility }}=0.443, \mathrm{P}<0.001, \beta_{\text {coordination flexibility }}=0.404\right.$, $\mathrm{P}<0.001)$.

(2) To test the impact of strategic flexibility on innovation openness. On the basis model 1, strategic flexibility (resource flexibility and coordination flexibility) is added to get model 2. Innovation openness is taken as dependent variable, and independent variables such as resource flexibility, coordination flexibility and control variables are regressed. The result is $\mathrm{R}^{2}=0.643$, adjusting $\mathrm{R}^{2}=0.624, \mathrm{~F}=33.844(\mathrm{P}<0.001)$. It shows that there is a significant positive correlation between strategic flexibility and innovation openness ( $\beta_{\text {resource flexibility }}=0.555, P$ $<0.001, \beta_{\text {coordination flexibility }}=0.2444, \mathrm{P}<0.01$ ).

(3) To examine the mediating role of innovation openness between strategic flexibility and business model innovation. Model 8, based on model 7, uses the mediating variable "innovation openness" as an independent variable to make a regression test. The result is $\mathrm{R}^{2}=0.758$, adjusting $\mathrm{R}^{2}=0.743, \mathrm{~F}=48.658(\mathrm{P}<0.001)$. The test results prove that the mediating effect of innovation openness is exists. $\mathrm{H} 2, \mathrm{H} 2 \mathrm{a}, \mathrm{H} 2 \mathrm{~b}$ are verified. Compared with model 7, after introducing "innovation openness", there is still a significant positive correlation between resource flexibility, strategic flexibility and business model innovation ( $\beta_{\text {resource flexibility }}=0.216, \quad \mathrm{P}<0.01$, $\beta_{\text {coordination flexibility }}=0.304, \mathrm{P}<0.01$ ). Therefore, the mediating role in judging innovation openness is a partial intermediary role.

\section{Testing the Moderating Effect}

To examine the moderating role of collaborator ties and competitor ties in strategic flexibility to innovation openness. Model 3 adds collaborator ties and competitor ties as independent variables on the basis of model 2, and model 4 adds interaction items on the basis of model 3 . The interaction terms(resource flexibility *collaborator ties) is significant negative $(\beta=-0.176, \mathrm{p}<0.01)$. The interaction terms (coordination flexibility *collaborator ties) is significant positively $(\beta=0.097, \mathrm{p}<0.1)$. Therefore, $\mathrm{H} 3$, the moderating role of collaborator ties is supported. Specifically, the collaborator ties negatively moderating the first half of the impact of resource flexibility on business model innovation through innovation openness; and positively moderating the first half of the impact of coordination flexibility on business model innovation through innovation openness.

The interaction terms(resource flexibility * competitor ties) is significant negative $(\beta=-0.11, p<0.05)$. The interaction terms (coordination flexibility * competitor ties) is significant positively $(\beta=0.109, \mathrm{p}<0.05)$. Therefore, H4, the moderating role of competitor ties is supported. Specifically, the competitor ties negatively moderating the first half of the impact of resource flexibility on business model innovation through innovation openness; and positively moderating the first half of the impact of coordination flexibility on business model innovation through innovation openness.

\section{Testing the Interaction Effect}

In order to further verify the impact of collaborator ties, competitor ties and strategic flexibility on innovation openness, model 5 takes innovation openness as dependent variable, In order to further verify the impact of collaborator ties, competitor ties and strategic flexibility on innovation openness, model 5 takes innovation openness as dependent variable, and conducts regression tests on three interactions of independent variables, moderate variables, independent variables * moderate variables, moderate variables $1 *$ moderate variables 2 and independent variables * moderate variables. The three interactive item is significantly correlated with innovation openness. (Resource Flexibility * Collaborative Ties * Competitor Ties : $\beta=-0.27, \mathrm{P}<0.01$; Coordination Flexibility* Collaborative Ties * Competitor Ties : $\beta=0.125, \mathrm{P}<0.05, \mathrm{R} 2=0.783$, adjusting $\mathrm{R}^{2}=0.747$ ). This supported the hypothesis $\mathrm{H} 5$ that cooperator ties $*$ competitor ties have a synthetical moderating effect. Specifically, in the synthetical moderating effect of competitor ties and collaborator ties, negatively moderating the first half of the impact of resource flexibility on business model innovation through innovation openness; and positively moderating the first half of the impact of coordination flexibility on business model innovation through innovation openness. 
Table 4. Hypothesis Test

\begin{tabular}{|c|c|c|c|c|c|c|c|c|}
\hline \multirow[b]{2}{*}{ variable } & \multicolumn{5}{|c|}{ innovation openness } & \multicolumn{3}{|c|}{ business model innovation } \\
\hline & $\begin{array}{l}\text { Model } \\
1\end{array}$ & $\begin{array}{l}\text { Model } \\
2\end{array}$ & $\begin{array}{l}\text { Model } \\
3\end{array}$ & Model 4 & $\begin{array}{l}\text { Model } \\
5\end{array}$ & $\begin{array}{l}\text { Model } \\
6\end{array}$ & $\begin{array}{l}\text { Model } \\
7\end{array}$ & $\begin{array}{l}\text { Model } \\
8\end{array}$ \\
\hline control variable & & & & & & & & \\
\hline Enterprise Age & -0.069 & -0.004 & 0.034 & 0.043 & 0.021 & -0.035 & -0.024 & -0.022 \\
\hline Enterprise size & 0.066 & 0.058 & 0.054 & 0.031 & 0.012 & 0.063 & 0.06 & 0.09 \\
\hline $\begin{array}{l}\text { Types of Enterprise Ownership } \\
\text { independent variable }\end{array}$ & -0.107 & -0.112 & -0.06 & -0.053 & -0.039 & -0.051 & -0.023 & 0.023 \\
\hline Resource Flexibility & & $\begin{array}{c}0.555^{* *} \\
*\end{array}$ & $\begin{array}{c}0.295 * * \\
*\end{array}$ & $0.31 * * *$ & $\begin{array}{c}0.323^{* *} \\
*\end{array}$ & & $\begin{array}{c}0.443^{* *} \\
*\end{array}$ & $0.216^{* *}$ \\
\hline Coordination flexibility & & $0.244 * *$ & $0.19 *$ & $0.207^{*}$ & $0.219 *$ & & $\begin{array}{c}0.404 * * \\
*\end{array}$ & $\begin{array}{l}0.304 * * \\
*\end{array}$ \\
\hline $\begin{array}{c}\text { Mediate variable } \\
\text { innovation openness }\end{array}$ & & & & & & & & $\begin{array}{l}0.409 * * \\
*\end{array}$ \\
\hline Moderate variable & & & & & & & & \\
\hline Collaborator Ties & & & $\begin{array}{c}0.509 * * \\
*\end{array}$ & $\begin{array}{c}0.350 * * \\
*\end{array}$ & $0.119 *$ & & & \\
\hline Competitor Ties & & & $\begin{array}{c}-0.125 * \\
*\end{array}$ & $-0.142 * *$ & $-0.13 * *$ & & & \\
\hline Two Interaction effect & & & & & & & & \\
\hline Resource Flexibility * Collaborator Ties & & & & $-0.176^{* *}$ & $-0.317 *$ & & & \\
\hline Resource Flexibility * Competitor Ties & & & & $-0.11^{*}$ & $-0.157 *$ & & & \\
\hline Coordination flexibility $*$ Collaborator Ties & & & & $\begin{array}{c}0.097 \\
(+)\end{array}$ & $0.148^{* *}$ & & & \\
\hline Coordination flexibility $*$ Competitor Ties & & & & $0.109^{*}$ & $0.194 * *$ & & & \\
\hline Collaborator Ties * Competitor Ties & & & & & $0.127 *$ & & & \\
\hline Three Interaction effect & & & & & & & & \\
\hline $\begin{array}{c}\text { Resource Flexibility } * \text { Collaborator Ties } * \\
\text { Competitor Ties }\end{array}$ & & & & & $-0.27 * *$ & & & \\
\hline $\begin{array}{c}\text { Coordination flexibility } * \text { Collaborator Ties * } \\
\text { Competitor Ties }\end{array}$ & & & & & $0.125^{*}$ & & & \\
\hline $\mathbf{R}^{2}$ & 0.219 & 0.643 & 0.759 & 0.765 & 0.783 & 0.244 & 0.699 & 0.758 \\
\hline$\Delta \mathbf{R}^{2}$ & - & 0.424 & 0.116 & 0.006 & 0.018 & - & 0.455 & 0.059 \\
\hline Adjusted $\mathbf{R}^{2}$ & 0.195 & 0.624 & 0.741 & 0.735 & 0.747 & 0.221 & 0.683 & 0.743 \\
\hline $\mathbf{F}$ & $\begin{array}{l}8.993 * \\
* *\end{array}$ & $\begin{array}{l}33.844 * \\
* *\end{array}$ & $\begin{array}{l}41.466^{*} \\
* *\end{array}$ & $\begin{array}{l}25.973 * \\
* *\end{array}$ & $\begin{array}{l}21.902 * \\
* *\end{array}$ & $\begin{array}{c}10.349 * \\
* *\end{array}$ & $\begin{array}{l}43.581^{*} \\
* *\end{array}$ & $\begin{array}{l}48.658^{*} \\
* *\end{array}$ \\
\hline
\end{tabular}

$+\mathrm{p}<0.1, * \mathrm{p}<0.05, * * \mathrm{p}<0.01, * * * \mathrm{p}<0.001 \quad$ (double tail test)

\section{Research Conclusions and Implications}

\subsection{Research Conclusions}

this study examines the relationship between strategic flexibility (resource flexibility, coordination flexibility), innovation openness and business model innovation, and examines the moderating relationship between enterprises with competitors and partners in the business environment. Specifically, the conclusions are as follows:

(1) Innovation openness plays a mediating role between strategic flexibility and business model innovation, but this mediating role is partly. The result shows that strategic flexibility can not only have a direct impact on business model innovation, but also have an indirect impact on business model innovation through innovation openness.

(2) This study further explores the moderating role of new competitive and cooperative relationships between strategic flexibility and innovation openness in the current business environment. The result shows that collaborator ties negatively moderating the relationship between resource flexibility and innovation openness, positively moderating the relationship between coordination flexibility and innovation openness; competitor ties negatively moderating the relationship between resource flexibility and innovation openness, positively moderating the relationship between coordination flexibility and innovation openness; In addition, the results of three interaction shows that the relationship between resource flexibility and innovation openness is negatively moderated by high collaborator ties and high competitor ties, while the relationship between coordination flexibility and innovation openness is positively moderated by high collaborator ties and high competitor ties. 


\subsection{Implications}

Enterprises' strategic flexibility will affect the degree of interaction between enterprises and external innovators, also can affect the degree of resource utilization.

Resource flexibility focuses on the potential use of resources and the difficulty of resource transformation, which is determined by the intrinsic characteristics of enterprises' internal resources. The three interaction effects of resource flexibility* collaborator ties * competitor ties is negatively, which indicates that resource flexibility can improve the adaptability of enterprises to environmental changes, but at the same time make decision makers more insensitive to external changes. This is because excessive resource flexibility represents a high degree of organizational commitment and confidence in the original strategy. Excessive resource flexibility within the organization will make the enterprise unwilling to change the original competition strategy with the changes of the environment, resulting in managers being insensitive to the changes of the external environment and paying less attention to the changes of consumer demand or the actions taken by competitors.

Coordination flexibility emphasizes the ability of enterprises to redefine the direction of resource allocation, reconstruct and set the use of resources. The three interaction effects of Coordination flexibility * collaborator ties * competitor ties is positively correlated, which means that stronger coordination flexibility can help enterprises identify the degree of environmental change, find and discover new resources or new uses of existing resources, and promote enterprises' innovation activities. Collaborative ties are further embodied in the innovation caused by customer-oriented and supplier-oriented levels; competitor ties are further embodied in the innovation of product cost then promote competition. Higher coordinating flexible enterprises can promote innovation activities through good interaction with suppliers, customers and competitors.

Therefore, it is suggested that enterprises effectively integrate the relationship between internal resources with external competitors and cooperators according to their own strategic flexibility characteristics. Develop the enterprises' coordination flexibility from the perspective of competitor and collaborator ties, explore and integrate the knowledge inside and outside to promote the enterprise's technology development, resource development, and innovation activities. From the point of view of internal resource flexibility, enterprises tend to innovate under the condition of maintaining the status quo. Enterprises can commercialize advanced ideas within enterprises by combining the open innovation mode, or bring competitive advantages by means of economies of scale, etc.

Based on this, we suggest that the open innovation model should be embedded in enterprise activities. Enterprises can open their organizational boundaries through open innovation activities, promote the transformation of resources between organizations, also promote the transformation of customer knowledge and add customer value through the interaction process with customers. However, it should be point out that in the real business environment, excessive introduction of technology from outside weakens the R\&D capability of enterprises themselves, and excessive emphasis on self-R\&D level will face the possibility of high cost and high failure rate. Therefore, it is suggested that enterprises should integrate open innovation and internal R\&D organically in their activities according to their R\&D level and the industry technological development level.

\section{Acknowledgement}

Fund support: Shanghai Polytechnic University scientific research found project" Research on the adaptation mechanism of innovation process management in modern service enterprises" (EGD20XQD13)

\section{References}

Amit, R., \& Zott, C. (2001). Value creation in e-business. Strategic management journal, 22(6-7), 493-520. https://doi.org/10.1002/smj.187

Chesbrough, H. (2010). Business model innovation: opportunities and barriers. Long range planning, 43(2-3), 354-363. https://doi.org/10.1016/j.lrp.2009.07.010

Chesbrough, H., \& Rosenbloom, R. S. (2002). The role of the business model in capturing value from innovation: evidence from Xerox Corporation's technology spin-off companies. Industrial and corporate change, 11(3), 529-555. https://doi.org/10.1093/icc/11.3.529

D'Aveni, R. A., Dagnino, G. B., \& Smith, K. G. (2010). The age of temporary advantage. Strategic management journal, 31(13), 1371-1385. https://doi.org/10.1002/smj.897

Demil, B., Lecocq, X., Ricart, J. E., \& Zott, C. (2015). Introduction to the SEJ special issue on business models: business models within the domain of strategic entrepreneurship. Strategic Entrepreneurship Journal, 9(1), 1-11. https://doi.org/10.1002/sej.1194 
Ebersberger, B., Bloch, C., Herstad, S. J., \& Van De Velde, E. (2012). Open innovation practices and their effect on innovation performance. International Journal of Innovation and Technology Management, 9(06), 1250040. https://doi.org/10.1142/S021987701250040X

Eisenhardt, K., Furr, N., \& Bingham, C. (2010) Microfoundations of performance: Microfoundations of Performance: Balancing Efficiency and Flexibility in Dynamic Environments [J]. Organization Science, 2010. https://doi.org/10.1287/orsc.1100.0564

Faems, D., Van Looy, B., \& Debackere, K. (2005). Interorganizational collaboration and innovation: Toward a portfolio approach. Journal of product innovation management, 22(3), 238-250. https://doi.org/10.1111/j.0737-6782.2005.00120.x

Foss, N. J., Laursen, K., \& Pedersen, T. (2011). Linking customer interaction and innovation: The mediating role of new organizational practices. Organization Science, 22(4), 980-999. https://doi.org/10.1287/orsc.1100.0584

Gao, S., Xu, K., \& Yang, J. (2008). Managerial ties, absorptive capacity, and innovation. Asia Pacific Journal of Management, 25(3), 395-412. https://doi.org/10.1007/s10490-008-9096-1

Grimpe, C., \& Sofka, W. (2009). Search patterns and absorptive capacity: Low-and high-technology sectors in European countries. Research Policy, 38(3), 495-506. https://doi.org/10.1016/j.respol.2008.10.006

Guillen, M. F. (2000). Business groups in emerging economies: A resource-based view. academy of Management Journal, 43(3), 362-380. https://doi.org/10.5465/1556400

Hitt, M. A., Keats, B. W., \& DeMarie, S. M. (1998). Navigating in the new competitive landscape: Building strategic flexibility and competitive advantage in the 21 st century. Academy of Management Perspectives, 12(4), 22-42. https://doi.org/10.5465/ame.1998.1333922

Hoffmann, W. H., \& Schlosser, R. (2001). Success factors of strategic alliances in small and medium-sized enterprises-An empirical survey. Long range planning, 34(3), 357-381. https://doi.org/10.1016/S0024-6301(01)00041-3

Johnson, J. L., Lee, R. P. W., Saini, A., \& Grohmann, B. (2003). Market-focused strategic flexibility: Conceptual advances and an integrative model. Journal of the Academy of Marketing Science, 31(1), 74-89. https://doi.org/10.1177/0092070302238603

Katila, R., \& Shane, S. (2005). When does lack of resources make new firms innovative? academy of Management Journal, 48(5), 814-829. https://doi.org/10.5465/amj.2005.18803924

Laursen, K., \& Salter, A. (2006). Open for innovation: the role of openness in explaining innovation performance among UK manufacturing firms. Strategic management journal, 27(2), 131-150. https://doi.org/10.1002/smj.507

Laursen, K., \& Salter, A. J. (2014). The paradox of openness: Appropriability, external search and collaboration. Research Policy, 43(5), 867-878. https://doi.org/10.1016/j.respol.2013.10.004

Lazzarotti, V., Manzini, R., \& Pellegrini, L. (2011). Firm-specific factors and the openness degree: a survey of Italian firms. European Journal of Innovation Management, 14(4), 412-434. https://doi.org/10.1108/14601061111174899

Lee, S., Park, G., Yoon, B., \& Park, J. (2010). Open innovation in SMEs-An intermediated network model. Research Policy, 39(2), 290-300. https://doi.org/10.1016/j.respol.2009.12.009

Markides, C. (2006). Disruptive innovation: In need of better theory. Journal of product innovation management, 23(1), 19-25. https://doi.org/10.1111/j.1540-5885.2005.00177.x

Nadkarni, S., \& Narayanan, V. K. (2007). Strategic schemas, strategic flexibility, and firm performance: The moderating role of industry clockspeed. Strategic management journal, 28(3), 243-270. https://doi.org/10.1002/smj.576

Peng, M. W., \& Luo, Y. (2000). Managerial ties and firm performance in a transition economy: The nature of a micro-macro link. academy of Management Journal, 43(3), 486-501. https://doi.org/10.2307/1556406

Sanchez, R. (1995). Strategic flexibility in product competition. Strategic management journal, 16(S1), 135-159. https://doi.org/10.1002/smj.4250160921

Sanchez, R., \& Mahoney, J. T. (1996). Modularity, flexibility, and knowledge management in product and organization design. Strategic management journal, 17(S2), 63-76. https://doi.org/10.1002/smj.4250171107 
Schamberger, D. K., Cleven, N. J., \& Brettel, M. (2013). Performance effects of exploratory and exploitative innovation strategies and the moderating role of external innovation partners. Industry and Innovation, 20(4), 336-356. https://doi.org/10.1080/13662716.2013.805928

Schneider, S., \& Spieth, P. (2013). Business model innovation: Towards an integrated future research agenda. International Journal of Innovation Management, 17(01), 1340001. https://doi.org/10.1142/S136391961340001X

Takeishi, A. (2001). Bridging inter-and intra-firm boundaries: management of supplier involvement in automobile product development. Strategic management journal, 22(5), 403-433. https://doi.org/10.1002/smj.164

Teece, D. J. (1998). Capturing value from knowledge assets: The new economy, markets for know-how, and intangible assets. California management review, 40(3), 55-79. https://doi.org/10.2307/41165943

Van de Vrande, V., De Jong, J. P., Vanhaverbeke, W., \& De Rochemont, M. (2009). Open innovation in SMEs: Trends, motives and management challenges. Technovation, 29(6-7), 423-437. https://doi.org/10.1016/j.technovation.2008.10.001

Veugelers, R., \& Cassiman, B. (1999). Make and buy in innovation strategies: evidence from Belgian manufacturing firms. Research Policy, 28(1), 63-80. https://doi.org/10.1016/S0048-7333(98)00106-1

Zahra, S. A., Hayton, J. C., Neubaum, D. O., Dibrell, C., \& Craig, J. (2008). Culture of family commitment and strategic flexibility: The moderating effect of stewardship. Entrepreneurship theory and practice, 32(6), 1035-1054. https://doi.org/10.1111/j.1540-6520.2008.00271.x

\section{Copyrights}

Copyright for this article is retained by the author(s), with first publication rights granted to the journal.

This is an open-access article distributed under the terms and conditions of the Creative Commons Attribution license (http://creativecommons.org/licenses/by/4.0/). 